\section{West Germans help the East}

\section{Bonn}

IN an attempt to stem the tide of East German academics flooding westwards, the West German research agency DFG (Deutsche Forschungsgemeinschaft) announced last week that it would allocate new money to support collaborative projects between East and West Germany. This will be the first time since 1945 that DFG has supported projects in East Germany,

Grant applications must be submitted jointly by a West and an East German partner, and will be evaluated through the same peer-review procedure that DFG normally uses. DFG has asked the government for DM5-6 million (\$3-\$3.6 million) in additional funds in 1990 to finance the programme, estimating that about 100 new projects could then begin. But DFG president Hubert Markl said the plan "will go ahead even if we don't get the money", and declared "We must respond now to this situation," even if it means making sacrifices.

President Heinz Bethge of the Akademie Leopoldina in Halle welcomed the DFG programme as a way to help East Germany begin rebuilding a science infrastructure weakened by years of Communist Party favouritism. The Akademie Leopoldina, which was founded in 1652, eight years before the Royal Society of London, is one of the few organizations that remained relatively free of Communist influence.

Bethge said that the money was needed to "wake the frustrated generation" of researchers, some of them now in their fifties, who were kept down by the system of party privilege, said Bethge. "Giving these people courage is our only hope" for rebuilding East German science, he said.

The West German Research Ministry (BMFT) is likely to follow DFG with an East German cooperative programme on a much larger scale.

Preliminary reports say BMFT will request an additional DM40 million in the 1990 budget for projects in East Germany. In addition, permission is expected to be granted by the Finance Ministry for

BMFT to redirect DM40 million in the current 1990 budget for East German projects. The money will be awarded in areas of applied science such as nuclear reactor safety, coal technology, telecommunications, microelectronics, materials research, and in support for 'technology-orientated companies'. Like DFG, BMFT put the emphasis on collaboration. "We're not the "GDR Development Ministry'," said a BMFT spokesman. "We expect at least minimal input from East Germany in all these areas." But he hinted that as much as DM1,000 million could be directed through other ministries' budgets for investment in East Germany. That money might be used for projects such as a modernization of East Germany's inefficient and heavily polluting coal-fired power plants.

Despite the enthusiasm, there is a feeling of tentativeness at both DFG and BMFT about the future of these programmes. Both assume that the money will be invested in a sovereign East German state, but there is a growing feeling that East Germany may not last long. One observer gave independent East Germany a "half-life" of six months.

East Germans, researchers included, have forced politicians to act on reunification by simply heading to the West. In an admittedly unscientific sample, Hermann Scheuer of the Large Research Establishments (AGF) in Bonn reported that between 9 November and mid-January, nearly one East German researcher per day was contacting AGF from West Germany, asking about job opportunities.

Markl emphasized that DFG wants to encourage researchers to remain in East Germany. "If they come to the West", he said, "they will have to compete for funding with all of the groups already established here." But he denied that standards would be lowered for the joint applications.

Markl admitted that a few million deutsche mark would not overcome the entrenched Communist power structure in the scientific establishment in East Germany. "We're not so naive to think INDIA

\section{Sex selection continues in Maharastra}

\section{Bangalore}

LeGiSLATIVE attempts to prevent the selective abortion of female fetuses in India's western state of Maharastra have failed, according to an Indian pressure group, the Forum against Sex Determination and Sex Pre-selection. In 1988, Maharastra enacted India's strictest legislation on the issue, banning the use of amniocentesis for fetal sex determination. But the political will needed to implement the act has failed to materialize and nationwide legislation on the misuse of medical techniques in sexselective abortion is still lacking.

The Maharastra act lays down detailed procedures for complaints. But in a recent test case, the forum found it was impossible to get the government to take action against a clinic that advertised sex determination services.

\section{Appeal for help}

\section{Bonn}

BENNO Parthier, the president-elect of the Akademie Leopoldina in Halle, East Germany (see left), appealed to university professors in the West to come to East Germany to teach. "We desperately need the kind of help that only professors trained in the West can give", implored Parthier; "we would welcome visitors from the United Kingdom, France or anywhere else who would like to come and share their expertise with our students." Parthier said he was sure that East German students understood enough English to listen to lectures in that language as well as in German. President Hubert Markl of the DFG added his voice to Parthier's appeal, asking West Germans in particular to help. "I'm convinced that they would return from the experience personally enriched," he said.

As there is no central authority for arranging guest professorships at East German universities, those who are interested should get in touch with the universities directly or with the Deutsche Akademie der Naturforscher Leopoldina, AugustBebel-Strasse 50a, DDR-4010 Halle, German Democratic Republic, telephone 37-46-25014.

Steven Dickman

that the people who will get some of the money are not the same" as the ones who set up the old structure, he said. But by directing the programme toward individual researchers instead of institutions, DFG hopes to encourage a new structure.

Bethge agreed enthusiastically with Markl's logic. "Eighty per cent of university professors were in the Party", he said, which helped contribute to a "slide" in scientific standards. Sixty per cent of these people should just be "thrown out", said Bethge, but he admitted that this kind of "denazification" is not possible. "All we can do is try to replace them slowly with better people" selected from the ranks of the frustrated, he said.

Biochemist Benno Parthier warned that even with help from the West there would be difficult days ahead for East German science. The decline in scientific standards over the past ten years matches the decline in the economy revealed after the Communist government fell. The increase in patents reported by the academy in 1989 , 10 per cent more than in the previous year, is a "meaningless statistic," said Parthier: the patents are mostly worthless.

The science minister of the interim East German government, Peter-Klaus Budig, offered only disappointment to basic researchers at a recent plenary session of the Academy of Sciences, Parthier reported. Budig's top priorities for science were "energy policy, transport problems and communication problems"; biology was listed tenth.

Steven Dickman 